\title{
's Lands wijs, 's lands eer : een verkenning van het vakgebied internationale berichtgeving
}

Citation for published version (APA):

Brink, H. L. (1989). 's Lands wijs, 's lands eer : een verkenning van het vakgebied internationale berichtgeving. Wolters-Noordhoff. https://doi.org/10.26481/spe.19890901hb

Document status and date:

Published: 01/09/1989

DOI:

10.26481/spe.19890901hb

Document Version:

Publisher's PDF, also known as Version of record

\section{Please check the document version of this publication:}

- A submitted manuscript is the version of the article upon submission and before peer-review. There can be important differences between the submitted version and the official published version of record. People interested in the research are advised to contact the author for the final version of the publication, or visit the DOI to the publisher's website.

- The final author version and the galley proof are versions of the publication after peer review.

- The final published version features the final layout of the paper including the volume, issue and page numbers.

Link to publication

\footnotetext{
General rights rights.

- You may freely distribute the URL identifying the publication in the public portal. please follow below link for the End User Agreement:

www.umlib.nl/taverne-license

Take down policy

If you believe that this document breaches copyright please contact us at:

repository@maastrichtuniversity.nl

providing details and we will investigate your claim.
}

Copyright and moral rights for the publications made accessible in the public portal are retained by the authors and/or other copyright owners and it is a condition of accessing publications that users recognise and abide by the legal requirements associated with these

- Users may download and print one copy of any publication from the public portal for the purpose of private study or research.

- You may not further distribute the material or use it for any profit-making activity or commercial gain

If the publication is distributed under the terms of Article $25 \mathrm{fa}$ of the Dutch Copyright Act, indicated by the "Taverne" license above, 
' $S L A N D S W I J S, " S L A N D S E E R$ 

"SLANDSWIJS,"SLANDSEER

\author{
Een verkenning van het wakgebied \\ Internationale berichtgeving
}

\begin{abstract}
REDE
in verkorte vorm uitgesproken bij de aanvaarding van het ambt van hoogleraar in de Bedrijfseconomie aan de Rijksuniversiteit Limburg
\end{abstract}

op vrijdag 1 september 1989

door

H.L. Brink RA

Wolters-Noordhoff Groningen 
1989 Wolters-Noordhoff bv Groningen, The Netherlands

Copyright(CH.L. Brink

Alle rechten woorbehouden. Niets uit deze uitgave mag worden verveelvoudigd, opgeslagen in een geautomatiseerd gegevensbestand, of openbaar gemaakt, in enige vorm of op enige wijze, hetzij electronisch, mechanisch, door fotocopieën, opnamen, of op enige andere manier, zonder voorafgaande schriftelijke toestemming van de uitgever.

All rights reserved. No part of this publication may be reproduced, stored in a retrieval system, or transmitted, in any form or by any means, electronic, mechanical, photocopying, recording or otherwise, without the prior written permission of the publisher. 


\section{Internationale Berichtgeving 1 2. De bedriffseconomische invalshoek en de relatie met wet-en regelgeving 2 \\ 3. Harmonisatie van wet-en regelgeving 9 \\ 4. De bijzondere plaats van Nederland en de rol van Philips daarbij 14}

Noten 17

Literatuur 23

Verantwoording 29 



\section{Internationale Berichtgeving}

Her is de gewoonte dat een leder die tot hooglerat word benoemd zijn ambt aanvaardi mer het houden van een inaugurele rede. Het doel wan deze rede is dat de hoogleraar zich voorstelt aan de universitaire gemeenschap door (en voor dit alternatief heb ik gekozen) een, ook voor leken, begripelijke toelichting te geven op zijn vakgebied". In mijn geval is dat de Internationale Berichtgeving. Wat is Internationale Berichtgeving, wat zijn de problemen, welke ontwikkelingen zijn er gaande, hoe liggen de raakvlakken met andere vakgebieden, enz. enz.

U zult het mij hopelijk niet kwalijk nemen als zo af en toe het woord Philps valt, de onderneming waar ik de praktijk van de internationale be richtgeving heb leren kennen.

Bij ieder vakgebied wordt "iets" (het "ervaringsobject") vanuit een bepaalde invalshoek (het "Kenobject") bestudeerd". Bij Internationale Berichtgeving is dat "iets", het ervaringsobject, de inhoud van de woomamelijk financiäle informatieverstrekking door ondernemingen en de wijze warop deze informatie tot stand komt. Berichtgeving is in dit verband een te beperkte vertaling van het Engelse "Accounting". Dit laatste begrip wordt in grote lijnen afgedekt door de eertijds zeer bekende definitie van "administreren". Administreren is het systematisch verzamelen, vastleggen, verwerken en verstrekken van informatie ten behoeve van het besturen en functioneren van een huishouding en ten behoeve van de verantwoording die daarover moet worden afgelegd ${ }^{3}$. De informatieverstrekking ten behoeve van thet besturen krijgt gestalte in de interne berichtgeving, in het Engels aangeduid als management accounting. De infomatieverstrekking ten behoeve van de verantwoording wordt angeduid als externe berichtgeving of in het Engels, financial accounting. $\mathbb{K}$ zal mij bij het witwoeren van mijn leeropdracht voomamelijk bezig houden met de externe berichtgeving, de interne berichtgeving is voor mij het meest.naastliggende vakgebied.

Volledigheidshalve, het bijvoeglijk naamwoord Internationaal will zeggen dat het vakgebied niet beperkt is tot de Nederlandse situatie en opvattingen.

Bij het ervaringsobject (wat wordt bestudeerd) zijn er een tweetal afzonderlijk te beschouwen situaties. In de eerste plaats is daar de in meerdere landen opererende onderneming, de multinational, die in de regel éen verslag moet geven van haar wereldwijde operaties (bijvoorbeeld de geconsolideerde jaarrekening). In de tweede plaats is er de international opererende gebruker van jaarrekeninginformatie die zich geconfronteerd ziet met informatie die verschilt naar gelang de gebruiken en/of de wetgeving in de werschillende landen. 
IK wil er op wijzen dat de wet-en regelgeving ook tot het ervaringsobject behoor: waarom is er wett- en regelgeving en wat zjin de gevolgen daturvan?

Woor de praktijk wan de externe berichtgewing is deze wet- en regelgeving van bijzonder belang. Door de wet- en regelgeving worden de lijnen van het speelveld getrokken waarbinnen het berichtgevingsspel gespeeld moet worden.

De aspecten (de kenobjecten) die aan Internationale Berichtgeving verbonden zijn, zijn velerlei. Ik will $U$ er twee, de belangrijkste, noemen.

Kijkt men door de bril van de bedrijfseconoom dan kan naar mijn mening het onderzoek voomamelijk als beschrijvend en verklarend worden gekarakteriseerd. Hoe is de berichtgeving en waarom is deze zo" Kijkt men echter door de brill van een jurist dan is naar mijn mening het karakter voornamelijk normerend. Hoe zou de berichtgeving moeten zijn' ${ }^{6}$ ? In de praktijk zijn deze twee invalshoeken echter nawwelijks te scheiden. Dii betekent dat de bedrijfseconoom die Internationale Berichtgeving als vakgebied heeft een grondige kennis moet hebben van de relevante wet- en regelgeving zonder nochtans een jurist te moeten zijn. De jurist die dit wakgebied heeft gekozen zal uiteraard over een grondige bedrijfseconom:sche kennis moeten beschikken. Of, zoals de jurist Van Schilfgaarde het zegt, het vennootschapsrecht is een liaison aangegaan met uitlopers van de bedrijfseconomie ${ }^{7}$.

Na deze algemene kennismaking met mijn vakgebied will ik een aantal hoofdproblemen rond Internationale Berichtgeving de revue laten passeren, te weten:

wat moer in de praktijk onder een bedrijfseconomische invalshoek worden verstaan; wat is de relatie met wet- en regelgeving;

waarom wordt er in steeds toenemende mate aangedrongen op harmonisatie van wet-en regelgeving;

wat is de bijzondere positie van Nederland in dit verband en welke rol heeft Philips daarbij gespeeld?

\section{De bedriffseconomische invalshoek en de relatie met wet- en regelgeving}

In Nederland bestaat reeds lang wetgeving voor de externe berichtgeving $x$ ij het dat deze tot 1971 beperkt van omvang was. Tot dat moment omvatte het slechts een enkel artikel in het Wetboek van Koophandel. Het werkingsgebied was beperkt tot de verslaggeving door Naamloze 
Vennootschappen. Het in de periode vór 1971 grotendeels ontbreken van wet-en regelgeving wordt nogal eens vergoelijkt door te wijzen op de goede vijwillige verslaggeving door Nederlandse ondernemingen. Danbiy kunnen vanwit een hedendags perspectief toch wel een aantal kantiekeningen worden geplatatst. Als voorbeeld neem ik Philips omdat deze ondememing door velen als een lichtend voorbeeld wordt beschouwd. Het eerste jaarverslag dateert van 1912, het jaar waxin het Philips-aandeel op de beurs werd geintroduceerd. Het duurde echter tot 1951 voordat de grootte van de Philips-omzet aan de openbaarheid werd prijs gegeven. Bij de activa (de bezittingen) was de laagst mogelijke waardering de beste. Lager dan én guldén ging men echter niet omdat in die situatie het activum nog steeds in de boekhouding voorkwam en bestaanscontrole via de boekhouding dus nog mogelijk was. Er werd afgeschreven voorzover de resultatenrekening het kon dragen. En, voor de accountants onder U, balans en resultatenrekening werden "nagezien en accoord bevonden" door de eigen interne accountant. Deze accountant, de heer $L_{\text {. }}$ de Vries overleed in februari 1931 waama extem accountant P. Klijnveld zijn taak ovemam

Voorzichtigheid was de belangrijkste grondslag. Zo lees ik in het jaarverslag 1938-1939 het volgende. Omdat het in de accountantsverklaring wat puntiger is omschreven heb ik die tekst genomen met weglating van de cijfers: "Wij zjjn op grond van ons onderzoek overtuigd, dat de Balans den juisten toestand der Vennootschap weergeeft, met dien verstande dat de kantoor- en fabrieksgebouwen en -terreinen, machines, toestellen, instrumenten, enz. kantoor- en fabrieksinventarissen voor enkele guldens in de Balans wookomen en dat overigens ruime voorzieningen zijn getroffen, voorts dat de "Reserve Herwaardering" en de "Extra Reserve voor Uitbreiding" werden verhoogd." Drie opmerkingen bij dit citaat. Allereerst dat deze vermelding uitsluitend bedoeld is om de toemmalige algemene gedragslin te typeren. In de tweede plaats, om de voorstanders van historische kosten als waardegrondslag geen onrecht te doen, een dergelijke waardering op éen gulden heeft hoegenaamd niets met historische kosten van doen" . Tenslotte moet opgemerkt worden, dat de rekening "Reserve. Herwaardering" niets met het toepassen van vervangingswaarde van doen had. Deze "reserve" werd gevoed door de valuta-omrekeningsverschilen op buitenlandse deelnemingen en de resultaten op beleggingen.

In de democratiseringsgolf die in de zeventiger jaren de gemoederen bezig hield $\mathrm{kwam}$ ook de door de ondernemingen te yerstrekken informatie in een stroomversnelling terecht. Dit leidde in 1971 tot een forse uitbreiding van de bestaande wetgeving: de Wet op de Jaarrekening wan Ondememingen". Hieraan zijn in latere harmoniseringsgolven ${ }^{12}$ een aantal uit andere EG-lidstaten geimporteerde elementen toegevoegd ${ }^{13}$.

Vanuit eer bedrijfseconomisch standpunt kunnen een 4-tal groepen van bepalingen binnen de huidige wetgeving worden onderscheiden. De 
volgorde warin ik deze groepen noem is die van een toenemende bedrufseconomische betekenis.

In de earste plaats zijn er de bepalingen waarbij de wetgever geen keuzemogelijheden bied:

eer deel yan deze bepalingen is gericht op de bescherming van bepalde participanten. Als voorbeeld kan genoend worden het voorschrift dat een onderneming, die deel uitmaakt van een groter economisch geheel, vrijstelling van publicatie van de eigen jaarrekening kan verkrijgen mits aan een aantal voorwaarden wordt voldaan. Onder andere dat het grotere geheel zich garant stelt voor de verplichtingen van die ondememing en informatie over dat grotere geheel word gegeven (de geconsolideerde jaarrekening)

een dew wan deze bepalingen is van formele aard. Zo is bij voorbeeld de indeling en de benaming, wan de posten van balans en resultatenrekening in hoge mate gestandaardiseerd".

Dit soort bepalingen zijn voor de bedrijfseconoom een gegeven, men moet er kennis van dragen, tot een enthousiaste beroepsuitoefening nodigen zij niet uit.

In de wweede plaats zijn er de bepalingen waarbij de wetgever een keuzemogelijkheid heeft gelaten. Ik wil U er slechts éên, maar wel de mins inziens belangrijkste, noemen namelijk artikel $384^{16}$. Hierin wordt de onderneming de keuze gelaten tussen een tweetal waarderingsgrondslagen: verkrijgings- dan wel wervaardigingsprijs (wat heeft het gekost) of actuele waarde (wat is het waard). Slechts de bedriffseconoom vermag deze keus te maken omdat deze keus in wezen een economische is. Wat zijn de kosten en waar kan de informatieve waarde van elk der altematieven op gesteld worden?

In de derde plaats zijn er bepalingen die eigenlijk slechts zeggen: ik, wetgever, laat $U$ bij dit onderwerp geheel de vrije hand, het enige wat ik U vraag is om op te schrijven in Uw verslag wat $U$ gedaan heeft. Dergelijke onderwerpen zijn de behandeling van belastingen in het kader van de toepassing van actuele waarde en de behandeling van valuta's ${ }^{18}$. Dit soort onderwerpen is vooral administratief-technisch dermate ingewikkeld dat slechts de bedriffeconoom, die goed kan boekhouden, deze problematiek kan owerzien en er plezier aan kan beleven.

In de vierde plaats bevat het jaarrekeningrecht een zogenaamd kapstokartikel. In dit artikel ${ }^{19}$ is de hoofdregel van de jaarrekeningwetgeving gegeven: Uw informatie dient een zodanig inzicht te geven dat een werantwoord 
oordeel over het door $U$ behaalde resultaat en Uw eigen vermogen (hoe rijk bent U) mogelijk wordt gemaakt. Hierbij dient $U$ zich te houden aan maatschappelijk aanvaardbare nomen. Deze hoofdregel reikt zower dat her zonodig de detailbepalingen van de wet terzijde schuift.

Bij onderwerpen die niet geregeld zijn dient in de geest van deze hoofdregel gehandeld te worden, een aantal van deze onderwerpen noemde ik U reeds.

Tk heb deze 4-deling gegeven om op $U$ over te brengen dat het Nederlandse jaarrekeningrecht in hoge mate het domein is van de bedrijfseconoom, uitzondering moet waarschijnlijk worden gemaakt voor die groep van bepalingen die ik als eerste heb genoemd en waarbij de wetgever geen keuzemogelijkheid heeft gelaten.

Nu komt waarschijnlijk de vraag bij $U$ op wat nu precies bedoeld wordt met die bedrijfseconomische bril waarmee naar de voornamelijk tinanciële informatieverstrekking door ondernemingen wordt gekeken. Dat kan op verschillende manieren.

In de eerste plaats is er de mogelijkheid om dit op een theoretisch wetenschappelijke wijze te doen. Door Brezet heel treffend aangeduid als "de jacht op het juiste bedrijfseconomische winstbegrip ${ }^{\text {"200 }}$. Deze benadering is vooral in Nederland gevolgd tot laten we zeggen omstreeks 1975. Het zijn de jaren geweest waarin met name Limperg en zijn denkbeelden een stenpel hebben gedrukt op het denken over problemen als wat is waarde en wat is winst. Vooral over het winstbegrip werd uitgebreid gediscussieerd. Is de winst zoals deze volgens de theoretici zou moeten worden bepaald op ondubbelzinnige wijze en met juistheid (het deel 'true' van 'true and fair') in de praktijk te bepalen. Het was in die jaren dat ik mij verdiepte in de beginselen van de bedrijfseconomie en het grootste gedeelte van de tijd werd besteed aan het wegen van de argumenten van voor- en tegenstanders. Wie deze schermutselingen rond het winstbegrip nog eens wil nalezen kan nog steeds het best terecht bij de samenvatting die Burgert hiervan op de Accountantsdag 1967 gaf $^{2}$.

Wat heeft deze theoretisch wetenschappelijke benadering uiteindelijk opgeleverd? Ik denk bijzonder weinig. Pogingen om dit theoretische winstbegrip (waarover bovendien geen eenheid van opvatting bestond ${ }^{22}$ ) in 1971 in de Wet op de Jaarrekening van Ondernemingen opgenomen te krijgen zijn mislukt. Tot heden is nog steeds niet in de wet geregeld wat winst is. Burgert wees er in 1967 reeds op dat:

het (dit is het theoretisch werenschappelijke winstconcept) een typisch Nederlandse leer is, welker betekenis aan onze taalgrenzen lijkt op te houden; 
de praktische toepassing van bedoelde letr zich tot ons land beperk en ook daar niet zeer verbreid is.

Navolging in andere landen, zoals in het Verenigd Koninkrijk (SSAP 16) en in de USA (FAS 33) is tijdelijk gebleken. Genoemde 'statements' zijn inmiddels alle weer ingetrokken. Af en toe is er toch weer een roep on een theoretisch gefundeerd winstbegrip doch de praktijk is kennelijk niet geinteressecrd. Het LASC stelde bij zijn woorstel om het aantal opties in zijn standaarden terug te brengen dat theoretisch het systeem van actuele warde meer relevante informatie geeft dan historische kosten. Omdat er zo weinig eenstemmigheid is over het systeem van actuele waarde en historische kosten het overheersende systeem is, wordt door het IASC aan historische kosten toch de voorkeur gegeven boven actuele waarde ${ }^{23}$.

Dit alles overziende kan deze theoretisch wetenschappelijke benadering niet meer als een objectieve bedriffseconomische bril worden beschonwd waardoor een hoogleraar Internationale Berichtgeving zijn studenten zou moeten laten kijken.

Een andere mogelijkheid is om overeenstemming over de te verstrekken financielle informatie te bereiken door te trachten het eens te worden over een aantal basisprincipes. Een voorbeeld hierwan is thet in de USA door de FASB ontwikkelde "conceptual framework" . De in deze "frameworks" opgenomen basisprincipes ontmoeten elk voor zich weinig weerstand noch bij theoretici noch bij practici.

Een tweetal basisprincipes springen er uit en het is toch wel vervelend dat juist deze twee met elkaar in strijd kunnen zijn. Ik bedoel hier het matching en het voorzichtigheidsbeginsel. Het matchingbeginsel, ook wel causaliteitsbeginsel genoemd, houdt in dat men posten waartussen een oorzakelijk verband staat in hum samenhang laat zien. Hiermede kan men het relatieve belang van elk van deze posten tonen. Het meest sprekende voorbeeld is het matchen van kosten en opbrengsten.. Dat een bepald produkt bij de verkoop 100 gulden heeft opgebracht krijgt pas een diepere betekenis als daar tegenover wordt gesteld dat dit produkt (bijwoorbeeld) 85 gulden heeft gekost. Uit dit voorbeeld blijkt al dat het belangrijkste toepassingsgebied van het matchingbeginsel bij de winst- en verliesrekening ligt. Het voorzichtigheidsbeginsel houdt in dat geen bedragen op de balans mogen worden opgevoerd waarover twijfel bestaat of hier in de toekomst voldoende opbrengsten tegenover zullen staan. Een bekend voorbeeld waurbij deze tegenstrijdigheid speelt, zijn de kosten van het ontwikkelen wan bepaalde produkten. Op basis van het matchingbeginsel zouden deze kosten op de balans moeten worden opgevoerd om op het moment van verkoop van deze produkten als kosten tegenover de opbrengst gesteld te worden. Op basis van het voorzichtigheidsbeginsel ontmoet het opvoeren op de balans echter weerstand omdat het onzeker is of de ontwikkelde produkten wel een commercieel succes zullen blijken te zijn. De wetgever 
in Nederland heeft dit dilenma voor de oniwikkelingskosten als volgt opgelost. Opvoeren van ontwikkelingskosten op de balans is toegestaan maar eenzelfde bedrag moet in een wettelijke reserve worden gebonden, dat wil zeggen: dat bedrag mag door de onderneming niet uitgekeerd worden aan haar aandeelhouders ${ }^{25}$.

Van deze benadering, met als centraal thema een aantal grondbeginselen, kan gezegd worden dat deze een goede aanzet geeft om vast te stellen welke kwalitatieve eisen aan een jaarrekening gesteld moeten worden. Voor de vaststelling van de inhoud van een jaarrekening is echter nawwelijks een bijdrage geleverd. Het is echter terecht dat in de opleiding tegenwoordig veel aandacht wordt besteed aan deze grondbeginselen.

Een derde mogelijkheid is om bij de gebruikers te onderzoeken wat hun informatiebehoeften zijn, waaruit dan de inhoud van de te verstrekken informatie volgt. Voor dit onderzoek zijn verschillende technieken beschikbaar die ik hier onbesproken moet laten ${ }^{26}$.

Dit onderzoek heeft in grote lijnen het volgende aan het licht gebracht:

de gebruiker is nauwelijks in staat gebleken zijn informatiebehoeften te definiëren. Waar deze behoeften wel gedefinieerd konden worden zijn ze per groep van gebruikers bijzonder divers ${ }^{27}$. Dit betekent in concreto dat eigenlijk voor elke groep van gebruikers een afzonderlijk verslag (een 'special purpose report') moet worden gemaakt. Er is zo weinig gemeenschappelijks in de informatiebehoefte dat één algemeen verslag (een "general purpose report') zoals wij dat kennen in de vorm van een jaarverslag c.q. jaarrekening slechts in weinig behoeften voorziet ${ }^{28}$.

Voor het meten van het nut is de invloed van de informatie op het gedrag van de gebruiker een belangrijk criterium. Uit onderzoek blijkt dat deze invloed er wel is, maar dat een belangrijk deel van het gedrag niet uit de reguliere externe berichtgeving kan worden afgeleid ${ }^{29}$.

Ik denk dat wij, gegeven deze uitkonsten, de gebruikers een poosje met rust moeten laten en ons richten op de andere partij bij de verslaggeving, de ondernemingen dus.

Genoemde drie benaderingen waren alle normatief, dat wil zeggen dat getracht werd de gewenste inhoud wan de exteme berichtgeving vast te stellen. Het resultaat van deze aanpak, ik vermeldde dit reeds, is dat in de Nederlandse wetgeving thans niet geregeld is wat winst is. Winst is in de praktijk datgene wat de verschaffers van de informatie daaronder verstaan. Het ligt dan ook voor de hand het onderzoek op de verschaffers, de ondernemingen dus, te richten. 
Dit onderyok is anders van aard. Het neemt de bestaande berichigeving als gegeven an en sielt "slechts" de wratg: waarom? Van de Poel heeft daarom de volgende le onderzoeken vragen in de "accounting agenda" laten noteren ${ }^{30}$.

waar een keuzevrijheid bestad, volgens welke criteria kan een ondememing het beste kiezen?

als er reeds een keuze is gedaan, kan deze achteraf verkllard worden?

heeft de wet- en regelgeving enig effect gehad op de keuze en zo ja, welke?

Hierbij dient aangetekend te worden dat bijna alle onderzoek zich tot dusverre op de inhoud van de gepubliceerde jaarrekeningen heeft gericht. Het door Van de Poel woorgestane onderzoek dient echter vooral gericht te worden op de owerwegingen en de beslissingen die tot deze inhoud hebben geleid.

Samengeval gaat het hier orm de stelselkeuze en stelselwijziging door de onderneming. Dat hier een rijk onderzoeksterrein ligt moge blijken uit de cijfers die Hoogendoorn tijdens het Pacioli-forum "Stelselwijzigingen in jaarrekeningen" toonde". Hoogendoorn onderzocht over de periode 1977 tot en met 1986, 1380 jaarrekeningen. Daarin constateerde hij 555 stelselwijzigingen; het aantal jaarrekeningen waarin één of meer stelselwijzigingen voorkwam was 399 , dit is $29 \%$.

Uit een Amerikaans onderzoek bleek dat de minder rendabele ondememingen er beter in slaagden hun resultaat te verbeteren door middel van stelselwijzigingen dan de beter renderende ondernemingen ${ }^{32}$. $U$ ziet, dit onderwerp biedt ook de wantrouwigen onder de bedrijfseconomen een breed perspectief. Bij het onderzoek moeten tamelijk gevoelige onderwerpen als "income smoothing" (het zodanig manipuleren van de winst dat een te lage winst wat hoger en een te hoge winst wat lager wordt) niet uit de weg worden gegaan. Al was het alleen maar om uitgesproken aantijgingen eventueel te weerleggen ${ }^{33}$.

Het onderzoek in de richting van de verschaffers geeft uiteraard geen garantie dat daaruit meer informatie over de inhoud van de jaarrekening beschikbaar komt dan uit het onderzoek richting gebruikers. Konden de gebrukers hun motiewen niet geven, het is niet ondenkbaar dat de verschaffers hun motieven niet willen geven. Opmerkelijk is dat de discussie over een goede verslaggeving in de literatuur overwegend wordt gevoerd door wetenschappelijke economen en accountants. Slechts een enkele keer legt een "verschaffer" zijn ziel in de openbaarheid bloot". 
Men hoor nogal eens de mening dat de verschaffers ongestraft en schijnbaar zonder beperkingen van stelsel kunnein veranderen. Sommigen zien de oplossing van dit probleem in het opnemen wan een aantal watborgen in de jaarrekeningwetgeving ${ }^{35}$. Zonder overigens am te geven wat deze warborgen zouden moeten inhouden. Het telkens wajzigen van stelsel is voor de gebruiker uiteraard een frustrerende situatie. Een stelselwijziging wordt door hen eerder ervaren als een vertroebeling dan als een verbetering van het inzicht, terwijl dit in veel gevallen door de onderneming als doelstelling of aanleiding wordt aangevoerd. De vergelijking met het verleden is immers niet meer mogelijk, behalve als de wet wordi gevolgd! De wet schrijft immers voor dat slechts wegens gegronde reden de indeling van balans en winst- en verliesrekening envof de grondslagen voor de waardering van activa en passiva en voor de bepaling van het resultaat van die van het voorafgaande jaar mogen afwijken. Is er een gegronde reden dan moet deze worden uiteengezet, herwijl de gevolgen van de wijziging moeten worden gekwantificeerd" ${ }^{3}$. Uit het eerder genoemde onderzoek van Hoogendoorn is gebleken dat hiemede nogal eens de hand wordt gelicht. In dat geval schort het echter niet aan de wet maar aan de handhavingsmogelijkheden. De oplossing moet dan ook daar worden gezocht. Gegeven de huidige procedure rond het klagen bij de Ondememingskamer ${ }^{37}$ mogen daar geen al te grote verwachtingen gesteld worden. De bereidheid tot het indienen van een klacht blijkt in de praktijk niet erg groot te zijn. Ook niet bij de Procureur General (het Openbaar Ministerie) nu de Ondernemingskamer heeft uitgesproken dat afwijken van de wet (in bedoeld geval) geen zaak was die het openbaar belang raakte ${ }^{\text {s. }}$.

Bij de controllersopleiding aan onze universiteit is ook de weg richting onderzoek bij de verschaffers ingeslagen. "Stelselwijziging in theorie en praktijk" is het grondthema voor het vak Externe Berichtgeving.

\section{Harmonisatie wan wet-en regelgeving}

In mijn algemene inleiding heb ik $U$ de twee situaties geschetst waarin verschil in gebruiken en/of in wet- en regelgeving aanleiding tot problemen kan gever. De multinational, die gegevens uit de verschillende landen tot een verslag moet combineren en de international opererende gebruiker, die kennis moet nemen van verslagen die op verschillende grondslagen zijn opgesteld. Volledigheidshalve wijs ik er op dat ook de gebruiker die binnen én land opereert met dit probleem wordt geconfronteerd indien en voorzover de wetgever keuzemogelijkheden aan de ondememingen heeft gelaten, zoals onder andere in Nederland, met name op het gebied van de warderingsgrondslagen, het geval is. 
De werts tot hamonisatie van wet-en regelgeving is bij de ondememingen in begimel adnwezig. Met dit probleem is de multinational echter reeds lang geleden vertrouwd geraakt. Mede met behulp van de automatiseringsmogelijkheden zijn daar redelijk efficient werkende noodoplossingen voor gevondein. De heer Appelo heeft deze onlangs in het Multinational-nummer wan het M.A.B. nog eens beschreven ${ }^{39}$. Dat de multinational slechts beperkt enthousiast reageert op de harmonisatie, zoals deze thans wordt bedrewen, heeft een aantal oorzaken.

In de eerste plaats heeft de harmonisatie slechts beperkte werking. Dat kan zijn omdat deze beperkt is tot een bepaalde regio. De hamonisatie van het vennootschapsrecht binnen de Europese Gemeenschap is daar een voorbeeld van. Het kan ook zijn dat de hamonisatie uitgaat van een orgaan dat geen rechtsbevoegdheid heeft. Daarom is het slagen van hamonisatiepogingen van internationale organen als het International Accounting Standards Committee ( $\angle A S C$ ), de OECD of de Verenigde Naties rolledig afhankelizk van de vrijwillige medewerking van de ondernemingen ${ }^{40}$. In het geval dat deze medewerking gegeven wordt, is de multinational echter nog steeds niet bevrijd var de nationale wetgeving in de landen wat ze opereert en bliff zij dus het probleem houden.

Een andere oorzaak is dat ondememingen wel uniformiteit willen maar dan wel met het eigen "systeem" als uitgangspunt. Wat dat betreft is er niets nieuws onder de zon. Aristoteles zei ook reeds: Simile simili gauder, wij vinden genoegen in wat ons gelijk is ${ }^{4}$.

Bij de harmonisatie kunnen een tweetal fasen worden onderscheiden. Een eerste fase waarbij binnen de harmonisatie plaats is voor de voortzetting van nagenoeg alle bestaande gebruiken. En dergelijke harmonisatiewet of -standaard wordt gekenmerkt door het grote aantal opties. Deskundigen kwamen binnen de $4 \mathrm{e}$ EEG-richtlin, welke harmonisatie van de jaarrekeningwetgeving beoogde, tot 160 opties of daaromtrent. Overzichten hoe deze opties in de $4 \mathrm{e}$ Richtlijn door de wetgevers in de verschillende lidstaten zijn benut zijn dan ook bijna complete boekdelen ${ }^{42}$. In dezelfde richting wijzen opmerkingen van de wetgever of andere betrokkenen bij het indienen van aanpassingswetten, dat de harmonisatie (gelukkig) nief tot wezenlijke verandering van de eigen wetgewing heeft geleid ${ }^{43}$.

Deze fase is echter onontbeerlijk om de betrokken ondernemingen achter het hamonisatievoorstel te krijgen. De volgende fase is die waarin het aantal opties wordt teruggebracht. Dan pas is er volgens velen sprake van een echt harmonisatieproces. $\mathrm{Bij}$ het $\mathrm{IASC}$ is dat laatste proces kortgeleden duidelijk op gang gekomen. Ik doel hierbij op het bekende, zo $U$ wilt beruchte voorstel nummer 32 warbij een aantal tot dusver toegelaten mogelijkheden tot "verboden", "toegelaten" of "bij voorkeur" werden verklaard". De in de $\mathbb{E E G}$-richtlijnen veelvuldig voorkomende term "tot aan latere coördinatie" is een voorbode dat deze 2 e fase ook binnen de Europese Gemeenschap in het verschiet ligt. Onderwerpen waarbij dit speelt 
zin veelal woor Nederland gevoelige: de toepassing van actuele watarde, de wardering van deelnemingen in de vennootschappelike jaarrekening op basis wan netto vermogenswarde ${ }^{45}$ en de rechtstreekse afboeking van goodwill op het eigen vermogen.

Bij de hamonisatic wia niet rechtens afdwingbare regelgeving, zoals nu bijwoorbeeld door het IASC wordt voorgesteld, moet toch een groot wragteken geplaatst worden. Beperking van het aantal opties zal er onvermijdelijk toe leiden dat de acceptatiegraad van de onderneming sterk zal teruglopen ${ }^{\text {fti }}$.

Nog een enkel woord over de harmonisatie vanuit het gezichtspunt van de verschaffer. Het voorstel van de IASC om het aantal opties in haar standaarden drastisch in te perken is geinitieerd door de 1OSCO, de International Organisation of Securities Commissions" Het aantal ondernemingen dat notering heeft aan meer dan éen effectenbeurs van internationale allure is zelfs wereldwijd gezien maar zeer klein. Aantallen wan 50 of daaromtrent worden genoemd. Het mag op zijn minst opmerkelijk genoemd worden dat terwille van dit geringe aantal ondememingen de keuzemogelijkheden van een oneindig groter aantal andere ondememingen zouden worden beperkt. Wat dat betreft begint ook het gezond verstand in Brussel. te zegevieren getuige het voorstel van een richtijn om het werkingsgebied van de $4 \mathrm{e}$ en de $7 \mathrm{e}$ Richtlijn in alle lidstaten terug te brengen tot de echte grotere ondememingen ${ }^{4 k}$. Ik mag er op wijzen dat in een groot aantal landen (wat de Europese Gemeenschap betreft vón de hamonisatie) de wet- en regelgeving beperkt is tot ter beurze genoteerde ondemeningen. Bij de niet-genoteerde ondernemingen liggen de verhoudingen in het algemeen zodanig dai in goed gemeen overleg de informatie-verstrekking geregell kan worden Een gedachte die in Nederland en de Europese Gemeenschap zeker het overwegen waard is.

Hamonisatie veronderstelt verscheidenheid. Deze verscheidenheid heeft mij tot de titel van mijn oratie "s Lands wijs, "s lands eer" geinspireerd. IK wil daarom over deze verscheidenheid ook een aantal opmerkingen maken.

leder land heeft zijn specifieke gebruiken. Nederland heeft zijn "Reserve Herwaardering" (een gevolg van het toepassen van de actuele waarde) ${ }^{49_{*}}$ Duitsland heeft zijn 'Sonderposten mit Rücklageanteil' (een gevolg van de omstandigheid dat de "commercielle" winst maatgevend is voor de fiscale winst $)^{50}$; in vele landen zoals Zweden en India is het verplicht uitgebreide overzichten wan de inkomens van alle werknemers bij te voegen (een gevolg van de in die landen gebruikelijke openbaarheid van inkomens); het rechts plaatsen op de balans wan bezittingen en het links plaatsen van schulden zoals ik zag in het jaarverslag van Philips Pakistan (een oude Engelse gewoonte ${ }^{51}$ die in Engeland zelf niet meer gevolgd wordt). Zelfs van een hoogleraar Internationale Berichtgeving mag evenwel niet verwacht worden dat hij van ieder land één typisch voorbeeld kent, laat staan dat hij 
alle gebruiken paraat heeft. Vandaar ook dat reeds lang pogingen worden ondernomen om hierin systeem te brengen.

Er bestan veel van deze schema"s, ze zijn onderling soms sterk verschillend naar gelang het criterium dat men voor de indeling kiest. Een ander kenmerk is dat het aantal groepen in de regel toeneemt naar mate de onderzoeker langer bezig is met deze materie, respectievelijk naar mate meer personen bij het onderzoek wordem betrokken"2. Ik begin hiemnede nog maar pas en daarom hanteer ik voor mijzelf niet meer dan twee hoofdgroepen warvan ik slechts én in een tweetal subgroepen heb onderverdeeld.

De twee hoofdgroepen die ik onderscheid bestaan enerzijds uit de verslaglegging in landen met een markteconomie (ook wel aangeduid als de kapitalistische landen), anderzijds de landen met een planeconomie (ook well aangeduid als de socialistische landenj. De doelstelling wan de bedrijfshuishouding (ik mag nu niet zeggen de onderneming) in deze gebieden is verschillend. Bij een markteconomie ligt het zwaartepunt van de verslaggeving op de winst (de doelstelling is immers om het verschil tussen kosten en opbrengst zo groot mogelijk te maken). Bij een planeconomie ligt het zwaartepunt van de verslaggeving op het realiseren van de geplande produktie bij een gegeven inzet van middelen (de doelstelling is immers het voorzien in een bepaald deel van de maatschappelijke behoefte). Het verbaast mij dat er zo weinig, in het bijzonder ook Nederlandse, literatuur is over de verslaggeving binnen deze planeconomiën ${ }^{33}$. Gegeven vooral ook de ontwikkeling dat Westerse ondernemingen in toenemende mate activiteiten gaan ondernemen in deze gebieden in de vorm van 'joint ventures" met locale maatschappijen ${ }^{54}$. Een interessante ontwikkeling voor ons bedrijfseconomen en accountants is dat in de USSR er ook een reconstructie ("Perestroika') binnen de "accountingwereld" bezig is welke in het Russisch wordt aangeduid als "khosraschet". Het is maar dat $U$ het weet ${ }^{55}$. Wij kunnen ons niet veroorloven deze ontwikkelingen ongemerkt aan ons te laten voorbijgaan.

Van de tweede hoofdgroep, die van de vrije-markteconomieën, weten wij uiteraard meer. De verschillen tussen deze landen zijn velerlei. Er is echter maar én verschil dat ik in dit verband vooralsnog essentieel genoeg vind om een subindeling te maken. Dit verschil vloeit ook weer voort uit de doelstelling van de jaarrekening. Er zijn landen waar de jaarrekening naast de eigenlijke doelstelling, informatieverstrekking in algemene zin, ook ondler invloed staat van de informatieverstrekking aan met name de fiscus. In sommige landen is het laatste soms zelfs de hoofddoelstelling. Duitsland is hiervan het typische voorbeeld; de in de jaarrekening getoonde winst is in principe het bedrag waarover belasting wordt geheven, het zogenaande "Massgeblichkeitsprinzip"s6. In andere landen is deze relatie wel aanwezig maar minder direct dan in Duitsland. Uit efficiencyoverwegingen worden in deze landen commerciële en fiscale jaarrekening gelijk dan wel zo dicht 
mogelijk bij elkaar gehouden. In onze Nederlandse ogen kan een dergelijke jaarrekening slechts bij toewal een zodanig inzicht geven dat een verantwoord oordeel mogelijk is over resultaal en vermogen. Of wat puntiger, de jaarrekening geeft geen getrouw beeld. Aan de wereiste van een "true and fair view" is niet voldaan. De reeds eerder genoemde EEGbepaling dat de hoofdregel der wet ("true and fair view") de detailbepalingen onder omstandigheden ter zijde schuift is dan ook in de aangepaste Duitse wetgeving niet opgenomen ${ }^{\text {s7 }}$.

Hiertegenover staan de landen waar de jaarrekening van fiscale smetten wrij is, voorbeelden hiervan zijn het Verenigd Koninkrijk en de USA. Op de indeling van Nederland kom ik nog terug; in mijn overgesimplificeerde overzicht staat Nederland in de hoofdgroep "vrije markteconomiën", subgroep "van fiscale smetten vrij".

Zelfs een dergelijk eenvoudig schema geeft reeds een dieper inzicht in bepaalde verschijnselen. Zo komt het waarderingssysteem actuele waarde behalve in Nederland bijna nergens anders voor dan in Latijns-Amerika. Daar wordt actuele waarde echter in de jaarrekening toegepast ondat het fiscaal cen toegestaan systeem is. In Nederland wordt het toegepast in het kader van de Nederlandse visie op een 'true and fair view'.

Kennis wan deze fundamentele verschillen en inzicht in de oorzaken daarvan zijn onontbeerlijk indien men streeft naar harmonisatie. Met 1992 vlak voor de deur kan niet aan de eventuele verdere harmonisatie van het vennootschapsrecht binnen de Europese gemeenschap voorbijgegaan worden. Deze speelt toch ook bij een "Europa zonder grenzen" een rol Als de twee belangrijkstite barrières op de weg naar verder harmonisatie zie ik het volgende:

voor die landen binnen de Europese Gemeenschap waar een nauwe binding bestaat tussen commerciële en fiscale jaarrekening betekent aanpassing van het jaarrekeningen-recht tevens (en voor Duitsland vooral) aanpassing van het fiscale recht. Dit kan leiden tot niet beoogde respectievelijk niet gewenste gevolgen, mede omdat er ook weer een relatie bestaat tussen het niveau van belastingheffing en het niveau van de sociale verzorging.

Berichtgeving, accounting, kan gezien worden als een uiting van cultuur. Deze opvatting wint hoe langer hoe meer veld ${ }^{58}$. In de dagbladpers heeft U regelmatig kunnen lezen dat Nederland en ook de andere lidstaten tot veel bereid zijn in het kader van 1992. Eén ding staat evenwel vast, de eigen cultuur moet behouden blijven". In de contacten met collega"s uit de wereld wan wetenschap, accountants en bedrijven is mij gebleken dat behoud van de Nederlandse accounting cultuur, veelal en niet ten onrechte aangeduid als "het hoge niveau", hoog in hun vaandlel staat geschreven ${ }^{60}$. 
Ik denk dan ook dat het niet zo'n vaart zal lopen met verdere harmonisatie wan hef jaarrekeningenrecht bimnen de Europese gemeenschap, gegeven ook wat reeds tot stand is gebracht. Eerder zie ik een bescheiden deregulering en een verschuiving van de harmonisatie naar internationaal opgestelde organen, zoals het LASC, zoals onlangs ook door de Voorzitter wan de Fêdération des Experts Comptables Européens is bepleit. Indien men dat wenst zall echter nog wel een of andere oplossing gevonden moeten worden woor het vrijblijvende karakter wan deze regelgeving ${ }^{6 !}$

\section{De bujzondere plaats wan Nederland en de rol van Philips daarbij}

In de door mij genoemde systematische indelingen van landen valt de plaats wan Nederland op, welk criterium ook gehanteerd wordt. In veel gevallen is woor Nederland een afzonderlijke groep gereserveerd ${ }^{62}$. Het ene geval dat Nederland als "niet te classificeren" wordt beschouwd wijst trouwens ook al op een bijzondere positie ${ }^{\text {b3 }}$.

Het is de moeite waard om jets over het ontstaan van deze bijzondere positie te zeggen met name ook om te kunnen beoordelen of deze positie verecht is. Vooraf wil ik er op wijzen dat het volgende niet gebaseerd is op een doorwrochte studie. Indien men in de praktijk werkzaam is, is er nauwelijks tijd om zich in het verleden te verdiepen, hoe interessant dat ook is. Meestal worden dergelijke onderzoeken slechts gedaan bij bijzondere gebeurtenissen. Misschien is bijwoorbeeld het komende 100 jarige bestaan van Philips voldoende reden om in de rijke administratieve geschiedenis van het Philips-concern te duiken en daarower iets te publiceren.

De bijzondere positie van Nederland kan mijns inziens als volgt verklaard worden. De ontwikkeling wan het vak externe berichtgeving, het hoofdbestanddeel van mijn leeropdracht, is in Nederland reeds zeer vroeg begonnen. De wortels liggen in het ontstaan van het accountantsberoep in Nederland. Uit de geschiedschrijving van het NIvRA blijkt, dat het accountantsberoep in feite ontstaan is uit het boekhouden. Een belangrijk deel van de rond 1900 fungerende "vooraanstaande" accountants waren in het bezit wan de akte Boekhouden $K$ XII. ${ }^{64}$. Ook Limperg behoorde daartoe. De grote verdienste van Limperg in deze ontwikkeling is geweest, dat hij een verbincling heeft gelegd tussen deze van oorsprong boekhoudkundig georiënteerde bedrijfseconomie en de algemene economie via zijn stelsel wan gecoördineerde waardebegrippen. Veelal aangeduid als de vervangingswaardeleer.

Het was echter vooral Goudeket, de eerste officieel gekwalificeerde accountant bij Philips, die deze leer in relatie tot de externe berichtgeving internationall naar buiten heeft gebracht, nadat eerst het vervangingswaardesysteem bij Philips in de externe verslaggeving was geïntroduceerd ${ }^{\text {t5 }}$. Daarnaast moet er op gewezen worden dat dit systeem ook bij Philips in de 
interne berichtgeving is toegepast, nadat de "wetenschappelijke lee" eerst tot een in de praktijk toepasbaar systeem was teruggebracht ${ }^{66}$.

Deze leer, respectievelijk dit systeem, werd met veel overtuiging uitgedragen. Ik citeer uit een interne notitie van een anoniem blijwende Philipsfunctionaris: "In de goeie oude tijd gedroeg ik me, wat betreft onze vervan" gingswardeleer, als een jverige zendeling. $\mathrm{k}$ wees op de verdoemenis en failissementen die bij het uitblijven van bekeringen zouden volgen en voor spelde dat spoedig de "ontwikkelde wereld" het Philips-systeen zou accepteren." In dit verband is het ook goed de periode tijdens en kort na de Tweede Wereldoorlog nog eens te memoreren, een periode waarin een reeks van door Philipsmedewerkers geschreven boeken het licht zag. Het meest bekende is wel bet Rekeningenstelsel geschrewen door de heer $\mathrm{P}$. Bakker "Hoofd van het Budgetbureau der N.V. Philips Gloeilampenfabrieken te Eindhoven"6\%". Deze typische Philips-literatum heeft er enorm toe bijgedragen dat het comptabele onderwijs in Nederland in ruime zin op een uniek hoog niveau is gekomen.

Het wordt nogal eens vergeten dat ook in andere landen, in het bijzonder de Angelsaksische, soortgelijke ontwikkelingen aan de gang zijn geweest. Ik noemde U reeds FAS 33 in de USA en SSAP 16 in het Verenigd Koninkrijk. Beide hebben ook een zeer lange woorgeschiedenis ${ }^{63}$ en het is toch wel intrigerend dat deze ontwikkeling in genoemde landen is doodgelopen en in Nederland een weliswati beperkte, maar toch wel boeiende, toepassing heeft verkregen. Ik denk dat de verklaring gezocht moet worden bij Philips waar men tot de dag van vandaag is blijwen geloven in de juistheid van hel systeen alhoewel het vasthouden aan een taditie ook een roll zal spelen. IK heb echter de stellige indruk dat de auteurs van de eerder genoemde indelingen een te eenzijdige nadruk hebben gelegd op het Philips-verslag en dit als maatgevend voor de Nederlandse situatie hebben genomen.

$U$ moet hieruit niet afleiden dat ik van mening ben dat Philips nu ook maar zo spoedig mogelijk van de actuele waardegrondslag in haar externe berichtgeving zou moeten afstappen (en in de interne berichtgeving zeker niet). De omstandigheden waaronder Philips opereert, maken dat in de berichtgeving niet voorbijgegaan kan worden aan prijsveranderingen. Een niet onbelangrijk deel van de activiteiten windt plaats in zogenaamde hyperinflatielandem. En bij een belangrijk deel van de produkten zijn de technologie-verbeteringen dermate groot dat er sprake is van een voortdurende kostprijs- en opbrengstclaling.

Wel ben ik van mening dat ik mij bij het uitvoeren van de leeropdracht "Internationale Benichtgeving" enigszins moet beperken bij het uitdragen van de typische Nederlandse opvattingen, zoals deze onder andere door Philips in de praktijk worden toegepast. Ik zal daarbij uiteraard niet zo ver gaan om deze opwattingen als "folklore" te bestempelen. Hier is nog steeds sprake van een stuk praktijk dat internationaal grote bekendheid, maar helaas weinig navolging, heeft verkregen. $\mathrm{Bij}$ de overdracht van deze kennis 
aan studenten moet de flosofie van deze winstbepaling de nadruk lanigen. De ingewikkelde rekenpartien die er gewoonlijk bij gepresenteerd worden kunnen beward blijwen tot het moment dat eventued daadwerkelijk tot inwering van een dergelijk system wordt owergegaan.

Ik heb vanmiddag cen aantal onderwerpen mogen noemen die mijns inziens nadere aandach verdienen en een aantal wegen gewezen die wij mijns inziens bij het vakgebied Internationale Berichtgeving zouden moeten opgaan. In het bijzonder heb ik $U$ genoemd: meer aandacht voor de berichtgeving in landen met planeconomien, gegeven het toenemende belang van het bedrijfsleven in die gebieden en verlegging van de onderzoeksbelangstelling natar de verschaffers van de internationale exteme berichtgeving. Verder heb ik de waarschuwing uitgesproken niet de fout te maken te veel aandacht te besteden aan de typisch Nederlandse opvattingen, respectievelijk de toepassing daarvan bij Philips. Bij mijn werk zal ik veel in aanraking, ik hoop niet in aanvaring, komen met een aantal nauw verwante vakgebieden. Ik werheug mij daarop en zal mij naar vermogen inzetten. Mijn praktijkerwaring zal mij daarbij hopelijk goed van pas komen; Limperg wees er reeds op dat het voedsel voor de groel van de wetenschap wordt gelleverd door de werkelijkheid ${ }^{69}$. Bij dit alles zal ik mij echter ook bewust moeten zijn van de wijze woorden die Prediker ons in dit verband woorhield: "En overigens mijn zoon, wees gewaarschuwd; er is geen einde aan het maken van veel boeken en veel doorvorsen is afmatting van het licham" "70. 


\section{NOTEN}

1. Regeling der inaugurele redes, Rijksuniversiteit Limburg, College van Dekanen, Maastricht 1 januari 1986.

2. Meij Jr. (1949).

3. Starreveld, R.W., Leer van de administratieve organisatie, Samson, Alphen aan den Rijn, 1963, p. 15. In latere drukken staat een enigszins afwijkende versie.

4. Zie bijvoorbeell: Maijoor, S., The economic theory of accounting regulation: an application to Dutch accounting legislation, Working Paper 89-005, Economische faculteit Rijksuniversiteit Limburg, Maastricht.

5. Deze benadering wordt aangeduid als 'positive accounting theory", zie Watts, Zimmerman (1986).

6. Deze benadering wordt aangeduid als 'normative accounting theory', zie Watts, Zimmerman (1986).

7. Van Schilfgaarde (1988).

8. Het inmiddels wervallen Artikel 42.

9. Zie het Verslag van den Raad van Commissarissen aan Aandeelhouders in het Jaarverslag over 1930; alle Philipsjaarverslagen zijn voor onderzoek ter beschikking op de Company Archives (tel. 040-757161).

10. Het gaat hier om het probleém van de stille en geheime reserves.

11. De jaarrekening is thans geregeld in het Burgerlijk Wetboek, Boek 2, Titel 9.

12. De belangrijkste hierwan zijn de aanpassing aan de 4e EEG-Richtlijn in 1984 en de aanpassing aan de 7 e EEG-Richtlijn die eind 1988 haar beslag kreeg.

13. Het meest sprekend komt dit tot uitdrukking in het onder omstandigheden moeten vormen van "wettelijke reserves".

14. Burgerlijk Wetboek, Boek 2, Artikel 403.

15. Besluit "Modellen Jaarrekening". 
16. Burgerlik Wetboek, Boek 2, Artikel 384, lid 1.

17. Burgerlik Wetboek, Boek 2, Artikel 390, lind 5.

18. Burgerlijk Wetboek, Boek 2, Artikel 384, lin 5.

19. Burgerlijk Werboek, Boek 2, Artikel 362.

20. Brezet (1986), p. 790.

21. Burgert (1967).

22. Een nagenoeg complewt overzicht van de mogelijke varianten geeft Brezet (1986), 813 pagina's!

23. IASC (1989).

24. Dit is een zeer omvangrijk werkstuk. Dat het ook beknopter kan bewijst het door het LASC uitgegeven Proposed Statement Framework for the Preparation and Presentation of Financial Statements.

In Nederland wordt de roep om een dergelijk conceptual framework nog niet al te luid gehoord. Zie Bearzatto (1967). Wellicht ook omdat de belangrijkste grondslagen in de Nederlandse wetgeving terug te vinden zijn. Zie Klaassen, Bak (1987).

25. Burgerlijk Wetboek, Boek 2, Artikel 365, lid 3.

26. Zie hiervoor bijwoorbeeld Huizing (1987).

27. Limperg Instituut (1984).

28. Huizing (1987); Mumford (1989).

29. Foster (1986).

30. Van de Poel (1989).

31. Ook vermeld in Hoogendoorn (1989).

32. Lilien, Mellman, Pastena (1988).

33. Voor een "critische" publicatie zie bij woorbeeld Nods, Wieringa (1988).

34. Spinosa Cattela (1986). 
35. Deze suggestie was opgenomen in de stelling voor het forum van het Kosten W Winst Dispuut Pacioli van de Erasmus Universiteit Rotterdam op 15 maart 1989.

36. Burgerlijk Wetboek, Boek 2, Artikelen 363, lid 4 en 384, lid 5.

37. Zie bijwoorbeeld de Greef, K., De Ondememingskamer doet het yoorzichtig, Account 1989.

38. De zaak Nedlloyd, zie bijvoorbeeld Het Financieele Dagblad van 31 matart 1989.

39. Appelo (1988).

40. Een aantal ondernemingen vermeldt dat bepaalde richtlijnen (vrijwillig) zijn gevolgd. Zie bijvoorbeeld de Jaarverslagen van "Shell" (achterste binnenzijde van de omslag) en van Ciba Geigy (Bazel, Zwitserland).

41. Van Dale, Groot Woordenboek der Nederlandse Taal, Utrecht/Antwerpen, 1984, p. 3702. Collega Schilder maakte mij erop attent, dat het hoogst onwaarschijnlijk is dat Aristoteles deze woorden heeft gesproken. Aristoteles sprak Grieks.

42. Bijvoorbeeld Groupe d'Etudes des Experts Comptables de la C.E.E. Réponses à l'enquête sur les options de la quatrième directive, Bruxelles 1984.

43. Zie bijwoorbeeld de Memorie van Toelichting Voorstel van Wet "Bijzondere bepalingen voor de geconsolideerde Jaarrekening" (Tweede Kamer 1983, nr. 3).

44. IASC (1989).

45. Artikel 33 van de 4 e EEG-Richtlijn opende een kennelijk tijdelijke mogelijkheid voor de toepassing van actuele waarde: "... in afwijking van ... en in afwachting van latere coördinatie....".

In de 4e EEG-Richtlijn was de waardering op netto-vermogenswaarde van "verbonden" onder-nemingen tot aan een latere coördinatie toegestaan. In de 7e EEG-Richtijn (Artikel 45) is deze mogelijkheid teruggebracht tot ondernemingen waarin invloed wan betekenis wordt uitgeoefend op het bestuur en het firnanciele beleid.

46. Appelo (1988).

47. IASC News, January 1989. 
48. Voorstel van een Richtlijn tot wijziging van "de $4 \mathrm{e}$ en $7 \mathrm{e}$ EEGRichtlijn" in verband met de afwijkingen voor kleine en middelgrote vennootschappen ...., Com (88) 292 def.

49. Burgerlijk Wetboek, Boek 2, Artikel 390.

50. Handelsgesetzbuch Drittes Buch, Erster Abschnitt, 247.3.

51. Kreuknier (1948).

52. Choi, Mueller (1984).

53. Eên van de uitzonderingen is het reiswerslag van Bulte (1988).

54. In de Sovjet-Unie zijn zo'n vierhonderd joint ventures geregistreerd waarvan $35 \%$ in bedrijf is. In China zijn er inmiddels all 16.000, alle in bedrijf (Friese, P., Een Russisch succes: joint venture nr. 16, NRC Handelsblad, 23 mei 1989).

55. Hambly, G., USSR is counting cost of Perestroika, World Accounting Report, April 1989.

56. Een typerend yoorbeeld hiervan is de afschrijving op de materiële vaste activa: "Bewegliche Gegenstände des Anlagevermögens. werden im Rahmen der steuerlichen Möglichkeiten degressiv abgeschrieben; dabei wird auf die lineaire Abschreibungsmethode itbergegangen sobald diese zu höheren Abschreibungen führt. Von steuerlichen Sonderabschreibungsmöglichkeiten wird im vollen Unfang gebrauch gemacht." (Geschäftsbericht der deutschen Philips Unternehmen).

57. Budde (1988) merkt hierover op dat een 'true view' in Duitsland niet bereikbaar is maar dat daardoor het geven van een 'fair view" een grotere nadruk moet krijgen: "Eine absolute 'Richtigkeit' im allgemeingültigen Sinne, die das Fehlen jeglichen Beurteilungsspielraums voraussetzl, ist jedoch mit den Mitteln des Jahresabschlusses von vornherein nicht erreichbar und kann daher auch nicht erwartet werden. Mithin liegt der Bedeutungsschwerpunkt der Generalnorm auf einer fairen Lagedarstellung, frei von jeder absichtlichen Beeinflüssung in die eine oder andere Richtung."

Ook in Nederland is 'true and fair' (het getrouwe beeld) kennelijk in discussie. In een redactioneel artikel in de Accountant van juni 1989 lees ik: "... Als het IASC-memorandum dan ook verder uitspreekt 'dat een jaarrekening bij aanwezigheid van verborgen reserves geen getrouw beeld kan opleveren', past de kanttekening dat dat onder omstandigheden van goed toezicht dus niet bezwaar!ijk behoeft te 
zijn." (Volten, 1989). Weliswaar ging het hier over Banken maar waarom zou dit niet gelden voor grote ondernemingen waarvan de betekenis ook essentieel is voor de Nederlandse economie (bijvoorbeeld omdat men de grootste particuliere werkgever is?) Wat blijft er in zo'n opvatting nog over wan een "gebruikersbenadering?".

58. Zie bijwoorbeeld: Ansari, Bell (1988); Hofstede (1987); Schreuder (1987).

59. Een greep uit vele voorbeelden: Mourik, M. Het Brusselse Paard van Troje, NRC Handelsblad van 20 mei 1989. Ook de resultaten van het onderzoek dat het Tilburgse Buro M-4 in opdracht van de ZuidOost-Pers verrichtte naar aanleiding van de Europese verkiezingen geven te denken. Het merendeel van de ondervraagden wenst hoegenaamd niets van de nationale rechten in een eengeworden Europa in te brengen. (Eindhowens Dagblad van 10 juni 1989).

60. Bijwoorbeeld de Voorzitter van het NIvRA, drs. J.L.M.J. Obers RA, waar hij in zijn openingsspeech op de Accountantsdag 1989 de aanpassing van de Nederlandse wetgeving aan de 8ste EEG-Richtlijn bespreekt.

In zijn toespraak tot het IASC op 14 april 1989 stelde de heer Nordemann, Voorzitter van de FEE (Fédération des Experts Comptables Européens) voor de huidige regelgeving in drie lagen (nationale wetgeving, Europese wetgeving en internationale "wetgeving") tơ twee te beperken. Aan een tot één bepaalde regio (EG) beperkte wetgeving heeft de 'European Industry' geen behoefte.

61. Bijvoorbeeld door het volgen van de standaarden van het LASC in de locale wetgeving verplicht te stellen (LASC ED 32, par. 9).

62. Berry (1987).

63. DaCosta-Bourgeois-Lawson Accounting Groups, zie Choi, Mueller (1984), p. 35.

64. De Vries (1985).

65. Voor de Tweede Werelloorlog waardeerde Philips haar activa, zeer conservatief, woor een deel op een gulden. In het jaarverslag 19451946 werd deze grondslag losgelaten: "Daar te verwachten is dat ook in de naaste toekomst nog belangrijke investeringen zullen plaatshebben, achten wij het tegenover aandeelhouders niet juist de traditie van afschrijwing op $\mathrm{f} 1$,- zonder meer voont te zetten." In de 
daarop wolgende jarten werd geactiveerd tegen "aanschaffingsprijs, onder aftrek van normale afschrijvingen, vermeerderd met een belangrijke toeslag yoor gestegen vervangingswaarde". (Jaarverslag 1947). In het jatrverslag 1951 werd een "echte" vervangingswaarde gentroduceetd: "Deze activa zijn gewaardeerd op basis van de vervangingswaarde, onder aftrek van de afschrijving". Deze wijziging werd gemotiveerd als een "gewijzigde opstelling van de balans, waardoor een beter inzicht van de vermogenspositie wordt verkregen". Van een werbeterd inzicht in de resultaten werd niet gerept.

66. Hiervan noem ik het aanpassen van het systeem $\mathrm{O}$. Bakker tot het winstbegrip 1958-1971 met als belangrijkste kenmerken het toepassen van de vervangingswaarde en het instandhouden van de algemene koopkracht van het eigen vermogen door het onder omstandigheden in aanmerking nemen wan een inflatieresultaat op het saldo nominalle middelen en een verlies als gevolg van een excessief technologische prijsdaling van voorraden. Verder het vereenvoudigen van SSAP 16 tot het winstbegrip 1981 - heden met als belangrijkste kenmerken het (nog steeds) toepassen van de vervangingswaarde en het in aanmerking nemen van een financieringscorrectie.

67. Zonder op wolledigheid aanspraak te maken noem ik Spinosa Cattela, J.E., Budgettering en budgetcontrole, Stenfert Kroese, Leiden 1946.

Bakker, $P_{*}$ De grondslagen van de bedrijfsbudgetering, Stenfert Kroese, Leiden, 1948.

Baart, J.A., De calculatie in de ondememing, Stenfert Kroese, Leiden, 1955.

Vries, J.A. de, De administratie van industriële ondernemingen, Samson, Alphen aan de Rijn, 1963.

Ploeg, M.J. van der, De administratie als hulpmiddel bij het bedrijfsbeheer, Samson, Alphen aan den Rijn (z.j.).

Kruijff, H.A.A., Vermeulen, $H$., Administratie en commercieel bedrijfsbeheer, Samson, Alphen aan den Rijn, (z.j.).

Meijers, J., Administratieve facetten in de kapitaalgoederenindustrie, Samson, Alphen aan den Rijn, 1964.

68. Voor de USA zie: Rosenfield (1981). Voor het Verenigd Koninkrijk zie: Whittington (1986).

69. Trompert (1988), p. 22.

70. Prediker 12:12, Bijbel in de nieuwe vertaling, NBG, Amsterdarn 1954. 


\section{LITERATUUR}

Ansari, S.L., Bell, J., Accounting and Culture - an exploration Paper prepared for the Annual Meeting of the American Accounting Association, Orlando, Florida, August 1988.

Appelo, H.H.A., De externe berichtgeving door multiriationale ondernemingen, Maandblad voor Accountancy en Bedrijfshuishoudkunde, december 1988 .

Bailey, D.T., Accounting in Socialist Countries, Routledge, London and New York, 1988.

Bak, G.G.M., Informatieverstrekking in de tweede golf, TVVS, 1983, nr. $83 / 6$.

Bearzatto, D.A., Een conceptual framework als basis voor de externe verslaggeving, de Accountant, oktober en november 1984.

Berry, I., The need to classify worldwide practices, Accountancy, October 1987.

Bindenga, A.J., Dutch accountancy, a managerial economics based approach. Pilot 13, NIvRA, Amsterdam, 1983.

Boukema, C.A., De belanghebbende in de jaarrekeningprocedure, Maandblad voor Accountancy en Bedrijfshuishoudkunde, juli/augustus 1988.

Bouma, J.L., Externe Verslaggeving: een probleemgebied in ontwikkeling, Maandblad voor Accountancy en Bedriffshuishoudkunde, juli/augustus 1988 .

Brands, J., Amsterdamsche school der bedrijfseconomie contra Rotterdamsche school?, in: Weerspiegelde gedachten, Bohn, Haarlem, 1948.

Brezet, J.C., Micro-economische en bedrijfseconomische winstbepaling, Bedrijfseconomisch Instituut van de Erasmus Universiteit, Rotterdam, 1986.

Budde, W.D., Das Verhältnis des 'True and Fair View' zu den Grundsätzen ordnungsmässiger Buchführung und zu den Einzelrechnungslegungsvorschriften, in Einzelabschluss und Konzernabschluss, Gabler, Wiesbaden, 1988. 
Bulte, J. Accounting in de Volksrepubliek China, Pacioli Journaal, september 1988.

Burgert, R., Bedriifseconomisch aanvaardbare grondslagen woor de gepubliceerde jaarrekening, De Accountant, september 1967.

Choi, F.D.S., Mueller, G.G., International Accounting, Prentice-Hall Inc., Englewood Cliffs, New Jersey, 1984.

Dekker, H.C. Van de leer van Waarde en Winst naar Maatschappelijke Berichtgeving, Maandblad voor Accountancy en Bedrijfshwishoudkunde, juli/ augustus 1988.

Foster, G., Financial Statement Analysis, Prentice-Hall Inc., Englewood Cliffs, New Jersey, 1986.

Goudeket, A., An application of replacement value theory, Maandblad voor Acountancy en Bedrijfshuishoudkunde, oktober 1960 .

Gray, S.J., Towards a theory of cultural influence on the development of accounting systems internationally, Abacus, Vol. 24, No. 1, 1988.

Hofstede, G., The cultural context of accounting, in: Accounting and Culture, Plenary Session Papers and Discussants' Comments from the 1986 Annual Meeting of the American Accounting Association Edited by B.E. Cushing, American Accounting Association, 1987.

Hoogendoorn, M.N., Ontwikkelingen in de bepaling wan vermogen en resultaat: $1977-1986$, De Accountant, april 1989.

Hoogendoorn, M.N., Stelselwijzigingen in de jaarrekening, in: Gehandhaafd, Erasmus Universiteit, Rotterdam, 1984.

Huizing, A., De gebruikersbenadering: gewenste feiten?, Maandblad woor Accountancy en Bedrijfshuishoudkunde, januari 1987.

Hulle, K. van, De harmonisatie van het vennootschapsrecht in de Europese Gemeenschap, in: Harmonisatie van Vennootschaps- en effectenrecht, Kluwer, Deventer, 1988.

International Accounting Standards Committee, Exposure Draft 32. Comparibility of Financial Statements, London, 1989.

Jameson, M., A practical guide to Creative Accounting. Kogan Page, London, 1988. 
Klaassen, J., Bak, G.G.M., Exteme Verslaggeving, Stenfert Kroese, Leiden/ Antwerpen, 1987.

Knoops, C.D., Over normen en normativiteit in de theorie van de winstbepaling, in: Gehandhaafd, Erasmus Universiteit, Rotterdam, 1985.

Knoops, C.D., Theoriën en "conceptual frameworks" in accounting, Pacioli Journaal, januari 1989.

Kreukniet, W. Supplement op practisch boekhouden, Eerste Stuk, hoofdstuk IV, De Engelse Methode, Delwel, 'sw Gravenhage, 1948.74

Landau, W.L., The Federal and State roles in regulating United States Business Corporations, in: Harmonisatie van Vennootschaps- en effectenrecht, Kluwer, Deventer, 1988.

Lilien, S., Mellman, M., Pastena, V., Accounting Changes: Successfu] versus Unsuccessful Firms, The Accounting Review, October 1988.

Limperg Instituut, Periodieke berichtgeving door ondernemingen, Amsterdam, 1984.

Meij Jr., J.L., Leerboek der Bedrijfseconomie deel I, Delwel, "s Gravenhage, 1949.

Mueller, G.G., Gernon, H., Meek, G., Accounting, An International Perspective, Irwin, Homewood, Illinois, 1987.

Mumford, M., Abbreviated Accounts, Accountancy, June 1989.

Nobes, C., Financial reporting in the EEC: why and how it differs, Management Accounting, April 1987.

Nobes, C.W., Classification of financial reporting practices, in Advances in International Accounting, Vol. 1, JAI Press Inc., 1987.

Nods, R., Wieringa, P.A., Wat zeggen de ciffers?, Bruna, Utrecht/Antwerpen, 1988.

OECD, Harmonization of Accounting Standards, Achievements and prospects, OECD, Paris, 1986, in het bijzonder Chapter 1.1, The interests and needs of preparers and users of financial statements.

Offeren, D.H. van, Waarde en winst en Externe Verslaggeving, Maandblad voor Accountancy en Bedrijfshuishoudkunde, juli/augustus 1988. 
Pacioli-Forum, Stelselwijzigingen in jaarrekeningen, Pacioli Journaal, thaast 1989.

Poel, J.H.R, van de, De Accounting Agenda: actuele problemen van de berichtgeving in onderwijs, onderzoek_en praktijk, Pacioli Joumaal, januari 1989.

Poel, J.H.R. van de, Als de tekenen bedriegen..., Wolters-Noordhoff, Groningen, 1988.

Raaijmakers, M.J.G.C., Nederlandse wetgeving inzake concernverhoudingen, TVVS 1983, nr. 83/6.

Rosenfield, P., A history of inflation accounting, Journal of Accountancy, September 1981.

Schilfgaarde, P. van, Vennootschapsrecht na 27 jaren, in: Tot Vermaak Van Slagter, Kluwer, Deventer, 1988.

Schreuder, H., Waarden en normen achter berichtgevingsvormen, in: Sociale Rekenschap, SMO Boek 19, Stichting Maatschappij en Onderneming, 1981.

Schreuder, H., Accounting research, practice and culture: a European perspective, in: Accounting and Culture, Plenary Session Papers and Discussants' Comments from the 1986 Annual Meeting of the American Accounting Association Edited by B.E. Cushing, American Accounting Association, 1987.

Slot, R., Winst, in: Reflecties op Limperg, Kluwer, Deventer, 1979.

Spinosa Cattela, R.C., Maatschappelijke berichtgeving: de visie van een verschaffer, in: Maatschappelijke Berichtgeving, Kluwer, Deventer, 1986.

Tas, L.G. van der, Implementatie van "a true and fair view" in Duitsland (1) en (2), Maandblad voor Accountancy en Bedrijfshuishoudkunde, maart en oktober 1987.

Thomas, A.P. The effects of organisational culture on choices of accounting methods, Paper presented at the American Association Annual Meeting, Orlando, Florida, 1988. 
Traas, L., Ondernemingsvisies en maatschappelijke berichtgeving; in: Sociale Rekenschap, SMO Boek 19, Stichting Maatschappij en Onderneming, 1981.

Trompert, K., Een Amsterdamse lente. Honderd jaar Limperg 1879 1979, Eburon, Delft, 1988.

Volten, H., Banken, redactioneel artikel in: De Accountant, juni 1989.

Vries, J. de, Geschiedenis der Accountancy in Nederland, Van Gorcum, Assen/Maastricht 1985.

Watts, R.L., Zimmerman, J.L., Positive Accounting Theory, Prentice-Hall Inc., Englewood Cliffs, 1986.

Wel, $\vec{F}$. wan der, Stelselwijzigingen in de jaarrekening, een empirisch onderzoek, in: Maatschappelijke Berichtgeving, Kluwer, Deventer, 1986.

Whittington, G., Inflation Accounting, An introduction to the debate, Cambridge Univerisity Press, Cambridge, 1986. 


$$
\text { ? }
$$




\section{Verantwoording}

Bij de voorbereiding van deze rede heb ik dankbaar gebruik gemaakt wan de adviezen van de heer J.H.R. van de Poel en van de opmerkingen op het eerste concept van de heren H.H.A. Appelo en J.F. Leeuwerik.

Voorts dank ik onze Maastrichtse secretaresses Nancy Vandeberg, Sylvia Cox, José van der Poel en Marianne Stijnen voor hun onmisbare steun bij de tekstwerwerking. 